\title{
ASSESSING STUDENTS' CHEMICAL UNDERSTANDING ON CLASSIFICATION OF MATTERS
}

\author{
Sitna Windia Risqi*, Iva Nur Azizah, Ifah Silfianah \\ Institut Agama Islam Negeri (IAIN) Tulungagung
}

\begin{abstract}
Chemistry subject is often considered difficult by some students, it is one of the features to lead misunderstanding of chemistry concept. Material is a basic concept that needs to figure out especially to make easier the concept of classifying material. The data analyzed using descriptive quantitative approaches with test items. The resets displayed that most of the study got difficulties differentiating elements, compounds, and molecules. They still gained complaints to categorized molecular elements and elements, molecular compounds and compounds, and atoms and ions.
\end{abstract}

Keywords: students' understanding, classification of matters, students' difficulty

\section{INTRODUCTION}

Chemistry is a scientific discipline that discusses the composition, structure, property, and transformation of a substance. The term was adopted from the Arabic term كيمياء which means an object or substance transformation. Chemistry is significantly associated with issues related to elements' or atoms' property, the compound formulation, the bond between atoms, the function of a material, and the reactions benefits for human living. Therefore, chemistry is an abstract discipline that involved materials, along with materials transformation and the associated energy.

In the teaching and learning process, most students perceive chemistry as a difficult subject since it discusses abstract theories that are difficult to be comprehended by students. Thus, it causes conceptual misunderstanding. To minimize that effect, a complete conceptual understanding is required. Sudijono (2013) argues that someone's ability to comprehend a concept appears after he or she remembers it. Comprehension is the second knowledge dimension, consisting of conceptual material. Chemistry concepts are mostly abstract. Abstract materials comprehension requires someone to activate the formal operational level of intellectual development. Dahar, (1989) mentions that the primary advancement during the formal operational period is the ability to think abstractly.

\footnotetext{
*Corresponding author: IAIN Tulungagung, Jalan Mayor Sujadi Tim No. 46 Kedungwaru, Tulungaggung 66221, Indonesia. Email: windiasitna690@gmail.com
} 
Dahar (1989), also adds that concepts become the bricks that established thought process, as the fundamental of higher mental process to formulate principles and generalizations, so that someone can properly comprehend a concept. Ibnu, (2003) in his study concludes that the resistance of students' chemical concept misunderstanding is high, so that the further learning level should repeat the material with a similar concept, but gives no significant result. Therefore, concept comprehension is essential in learning since the correct concept understanding helps students to store, absorb, and memorize the learned material. The memorization of chemical formulas and facts is beneficial for long-term memory, but it gives no assurance on students' conceptual understanding. Students have to understand the crucial points of every discussed material so that they can construct chemical concepts. It becomes the agent of students' low interest in chemistry learning.

Students obtain conceptual understanding from the results of their learning process. Conceptual understanding can be observed from students' ability to re-explain the discussed material using their own language, properly. Students with good conceptual understanding explain the material with their language and are not stuck in the book. Students have to correctly understand the basic concepts before they learn the more complex concepts (Maghfiroh, et al., 2016). The correct understanding becomes fundamental of the proper understanding of the more complex concepts (Jannah, et al. 2012). Students with incorrect conceptual understanding will perceive it as a difficult concept that becomes the bottom line of their learning. Thus, conceptual understanding holds a critical role in determining students learning results in chemistry (Alighiri, et al., 2018).

Conceptual comprehension is highly substantial to help students solve the issues by associating the concept they have comprehended. However, many students have issues in comprehending the chemical concept. The issues are possibly caused by their failure to properly understand the basic concepts so that they have difficulties comprehending the complex issues (Nakhleh, 1992). Besides, students may also forget the basic chemical concept since they do not perceive it as an essential aspect of their life. One of the indicators of students' difficulty in understanding that concept is their low test score on that particular concept. If they obtain a score that is far lower than the standard, then they have difficulties in learning.

Many researchers have investigated students' basic chemical concept understanding and misconception in the study of literature. Several studies discuss students' misconceptions on chemical coordination, nomenclature, and geometry (Arkoful, et al. (2015). Students' misconceptions in most of the materials discussed in chemistry have been identified in many studies. An example of studies on students' misconception is Andersson (1990) who investigate 
misconception on materials and their transformation, Nakhleh, (1992) and Taber, (2002) on chemical bond, Hanson, et al. (2012) on hybridization. Additionally, Junarti, Eny, and Rody have also investigated misconceptions on the physical and chemical reaction. From those studies, the misconception on the classification of material has not been conducted. This concept is substantial for students because the previous and next materials are associated with it. Thus, students' failure to understand this concept affects their understanding of the other concepts. Therefore, this study investigates students' understanding of material classification to identify any misconceptions.

This study aims to identify (1) the level of students' understanding of material classification; (2) students' ability to solve questions about material classification; and (3) students' ways to solve their misconception. The results of this study are expected to (1) obtain data on $12^{\text {th }}$-grade science students conceptual understanding and misunderstanding on material classification; (2) the data of $12^{\text {th }}$-grade science students' ability to answers questions about material classification, and (3) be used as a consideration for future research.

\section{METHOD}

The method adopted in this study was the descriptive method since the study aims to identify the misconception experienced by students from State Senior High School 1 Tulungagung. Sukmadinata (2011) explains that descriptive qualitative objective is to describe and illustrate the scientific and scientifically engineered phenomena, that observes the characteristic, quality, and association among the activity. Besides, this method gives no treatment, manipulation, or variables change, but it illustrates the actual condition.

The object in this study was students understanding of material classification, while the subjects were students from State Senior High School 1 Tulungagung who had received chemical material classification lessons. The instrument involved in this research was a test instrument with material classification concept. The test consisted of ten items, adopted from the instrument from research conducted by Avci, et al. (2014). The instrument had been declared valid and reliable, with a reliability coefficient of 0.80 .

The obtained data were analyzed through some stages of (1) scoring, (2) students' correct answer percentage calculation; (3) organizing items with the similar concept; (4) calculating the percentage of students with the correct answer; and (5) measuring students ability in completing the test.

\section{RESULTS}

The obtained data from the test results were tabulated and the students' misconception percentage was calculated to identify the level of students' conceptual comprehension. The 28 
students have completed the ten-item test that discussed the definition of chemical material, chemical particle, element, compound, atom, differences between atom and molecule, molecular element, differences between the element and molecular element, along with differences between compound and molecular compound. The test results were used to identify and measure students' misunderstanding, as presented in Table 1.

\section{Table 1}

\section{Students' Misconception}

\begin{tabular}{llc}
\hline No & Question & Students' Correct Answer \\
\hline 1. & What do you know about chemical material? & $7,1 \%$ \\
\hline 2. & What do you know about chemical particles? & $57 \%$ \\
\hline 3. & What do you know about elements? & $32 \%$ \\
\hline 4. & What do you know about compounds? & $39 \%$ \\
\hline 5. & What do you know about the atom? & $32 \%$ \\
\hline 6. & What are the differences between atoms and molecules? & $64 \%$ \\
\hline 7. & What do you know about molecular elements? & $85 \%$ \\
\hline 8. & What do you know about molecular compounds? & $75 \%$ \\
\hline 9. & What is the difference between an element and a molecular element? & $61 \%$ \\
\hline 10. & What is the difference between compound and molecular compound? & $36 \%$ \\
\hline
\end{tabular}

Most of the students make mistakes on the definition of chemical material (7.1\%), followed by the definition of element and atom (32\%). On the question about the differences between compound and molecular compound, $36 \%$ of students give the correct answer. The compound's definition is also one of the topics where most students encounter misconception, followed by a chemical particle $(57 \%)$. In the question of molecular compound and differences between atom and molecule, $61 \%$ and $64 \%$ of the students give the correct answer, respectively. Meanwhile, students make a relatively low mistake on the question about the molecular compound definition (75\% of students give a correct answer). Lastly, the topic that attains the lowest mistake is about the definition of molecular element ( $85 \%$ of students provide the correct answer).

\section{DISCUSSION}

Most of the students experience misunderstanding on the chemical material definition (only $7.1 \%$ of students give a correct answer), followed by the definition of element and atom $(32 \%$ of students give the correct answer. Besides, students also face relatively high misconceptions on the concept of the compound and molecular compound differences (36\% of students give the correct answer on each category). Most students encounter difficulties in directly explaining the definition of the concept asked in the instruments. However, they face no problem in giving the example of those concepts. 
The concept of chemical material definition remains to be the most challenging concept for senior high school students, even college students taking Chemistry Education major frequently associate chemical material as the objects learned in chemistry learning. Nurhafizah, et al., also discover that students have a low understanding of chemical material concepts. In this study, students define materials based on their shape, not based on their mass and ability to occupy space. This understanding deviates the concepts from experts, in which Syukri (2008), defines material as everything with mass that occupies space.

Many students with a low conceptual understanding of elements define it as a united substance, while the particle is pieces of small atoms or ions. Research conducted by Nurhafizah, et al. discovers that most of the students do not comprehend the concept of the element. In this study, students fail to define the element, while many of them are still have confusion about the periodic system of elements.

The concept of element and particle definitions are microscopic concepts so that they are required detailed explanation. The difficulty in understanding these concepts increases since most teachers only give lecturing. Thus, they are suggested to also provide relevant pictures and videos, so that students are interested and better understand the concept.

In the last concept, the differences between compound and molecular compound, most of the students define compound as the substance that constitutes molecular compound. Meanwhile, some other students define molecular compounds as the constituent atom of a compound. Thus, many students have low ability in differentiating compound and molecular compounds. It occurs due to students' low interest in learning or less detailed explanation from the teachers on that concept.

Students' presumption of chemistry as a difficult lesson appears because of their low confidence in completing the test and their low interest in reading. Several means that can resolve students' misconception include creating systematic ideas associated with the chemical concept in detail, and every time misconception occurs, it has to be directly clarified (Duit, et al., 2012). Additionally, teachers have to also cultivate the concepts clearly to the students, while also explain every stage of the concept, so that every student comprehends the delivered material, especially the students who have just know chemical concepts. The teacher also can give direct illustrations through relevant pictures and videos to reduce students' boredom, so that students can easily comprehend the material. 


\section{CONCLUSION}

The research findings indicate that most of the students face difficulties in differentiating elements, compounds, and the mixture. Besides, they also have issues in differentiating element and molecular elements, compound, and molecular compound, as well as atom and ion. Following these findings, some suggestions are composed. Learning media in the form of pictures and videos should be adopted in the learning process of the material classification concept. Besides, innovative learning should be used in this learning process since it has not been massively implemented in Indonesia. Thus, it also requires further studies. The learning process should accentuate the comprehension of the basic concept, rather than mere memorization of the chemical formulas. Since there have been many concepts that have not been investigated, so that future research should adopt different concepts to be studied to improve the education quality in the Millennial era to produce prepared and competitive human resources at the international level.

\section{REFERENCES}

Adadan, Emine (2014) Investigating the influence of pre-service chemistry teachers' understanding of the particle nature of matter on their conceptual understanding of solution chemistry, Chemistry Education Research and Practice, 219-238.

Andersson, B. (1990). Pupils conceptions of matter and its transformation (age12- 16). Studies in Science Education, 18, 53-85.

Anshory, Irfan. 2000. Acuan Pelajaran Kimia Kelas 1 SMU. Jakarta : Erlangga.

Adisendjaja, Yusuf Hilmi, Oom romlah (2007) Identifikasi kesalahan dan miskonsepsi buku teks biologi SMU, Seminar Nasional Pendidikan Biologi dan Biologi, 1-13.

Avci, Filiz, Burci Acar Sesen, Fatma Gulay Kirbaslar (2014) Determination of seventh grade students' understanding of certain chemistry concepts, ScienceDirect, 152 ( 602-606).

Brady,E James. (1994). Kimia Universitas. Jakarta : Erlangga.

Dahar, Ratna Wilis. (1989). Teori - teori Belajar. Jakarta. Erlangga.

Alighiri, Dante. Apriliana Drastisianti, dan Endang Susila Ningsih. (2018). Pemahaman Konsep Siswa Materi Larutan Penyangga Dalam Pembelajaran MultipleRepresentasi. Jurnal Inovasi Pendidikan Kimia. Vol 12. No 2. Hal 2192-2200.

Duit, R., Gropengiesser, H., Kattmann, U., Komorek, M., \& Parchman, I. (2012). The model of educational reconstruction-a framework for improving teaching and learning science. In D. Jorde \& J. Dillion (Eds.) Science education research and practice in Europe: Restrospective and prospective. , 13-47.

Hanson, R., Sam, A., \& Antwi, V. (2012). Misconceptions of understanding chemistry teachers about hybridisation. African Journal of Educational Studies in Mathematics and Science., 10, 12-14. 
Jannah, M., Ningsih, P., dan Ratman. (2016). Analisis Miskonsepsi Siswa Kelas XI SMA Negeri 1 Banawa Tengah Pada Pembelajaran Larutan Penyangga Dengan CRI (Certainty Of Response Index). Jurnal Akademika Kimia. Vol 5. No 2. Hal 85-90.

Maghfiroh, L., Santosa, dan Suryadharma, I. B., (2016). Identifikasi Tingkat Pemahaman Konsep Stoikiometri Pada pereaksi Pembatas Dalam Jenis-Jenis Reaksi Kimia Siswa Kelas X MIA SMA Negeri 4 Malang. (J-PEK) Jurnal Pembelajaran Kimia. Vol 1. No 2, Hal 32-37.

Nakbleh, Mary B (1992) Why some students don't learn chemistry: Chemical misconceptions, Journal of Chemical Education, vol. 69.

Nurhafizah, Husna Amalya Melati, Rahmat Rasmawan (2017) Deskripsi pemahaman konsep materi dan perubahannya siswa kelas $\mathrm{x}$ smk smti pontianak, 1-11.

Sam, arkoful, kai niebert, ruby hanson, ankrah kwarteng twumasi (2015) the model of educational reconstruction: scientists' and students' conceptual balances to improve teaching of coordination chemistry in higher education, International Journal of Academic Research and Reflection, Vol. 3 (7), 67-77.

Saputro, Agung Nugroho Catur dan Irwan Nugraha. 2007. Kimia : Seandainya Kebidupan tanpa Kimia? Jilid 1. Buku pelajaran kimia untuk siswa SMA/MA kelas X. Jakarta : Direktorat Pendidikan Madrasah, Direktorat Jenderal Pendidikan Islam, Departemen Agama RI.

Stavy, R. (2008). Learning Science in the Schools: Research Informing Practice. New Jersey: Lawrence Erlbaum: Hillsdale.

Sudijono, Anas. (2013). Pengantar Evaluasi pendidikan. PT. Raja Grafindo Persada. Jakarta

Sukmadinata, N.S (2011). Metode Penelitian Pendidikan. Bandung:Remaja Rosadakarya

Syukri. (1999). Kimia Dasar Jilid 1. Bandung: ITB.

Taber, K. S. (2002). Chemical misconceptions-Preventions, diagnosis and cure. (Vol. 1). London: Royal Society of Chemistry.

Yakubi, Malik, Zulfadli, Latifah Hanum, Menganalisis Tingkat Pemahaman Siswa pada Materi Ikatan Kimia Menggunakan Instrumen Penilaian Four-Tier Multiple Choice (Studi Kasus pada Siswa Kelas X SMA Negeri 4 Banda Aceh), Jurnal Ilmiah Mahasiswa Pendidikan Kimia (JIMPK), Vol 2 . No.1 (19-26). 